\title{
Process of building frames in TV channels
}

\author{
Tubagus Aditya Nugraha ${ }^{1}$ and Eriyanto Eriyanto ${ }^{1, *}$ \\ ${ }^{1}$ Postgraduate, Department of Communication, Universitas Indonesia, UI Salemba Campus, 16424
}

\begin{abstract}
The 2017 Jakarta gubernatorial election (Pilkada) 2017 in Indonesia bore considerable political significance. Issues surrounding ethnicity, religion, and race (SARA) posed problems that characterized this election, which impacted not only the community, but also the media. News channel Metro TVs became one of the affected TV stations after it got labelled as a supporter of Basuki "Ahok" Tjahaja Purnama, former Jakarta governor who was accused of and imprisoned for blasphemy thoroughout his reelection. Many activities oppossing Metro TV were conducted, starting from petition, the destruction of its broadcasting tool, and attacks to its journalist. This research aims to discover the actors behind the formation news framing in Metro $T V$ and also factors that caused the formation of such framing. This research uses a conceptual framework consisting of three factors, namely individual level, level of routine, and external level. Informants in this study are the staffs involved in Metro TV' editorial program. This research uses qualitative methods, including observatory and in-depth interview. This research concludes that factors of individual level, level of routine, and external level are interrelated and supportive in Metro TV's news framing in reporting Ahok.
\end{abstract}

\section{Introduction}

Media ownership is one of the ways for media to be separated from elite interests. Some researchers argue that it is very important for audience to see or know who the owner of the media is so that the audience has an audience [1]. This is because ownership is believed to affect news content and journalism. Besides, in an effort to maximize profits for the company, media often limits the diversity of views presented. Ultimately, this is seen as a detrimental act toward democracy, which relies on a free and independent press that is responsible to support citizens acquiring informed knowledge [1].

The practices of the elites of mass media companies also create other various adverse impacts, especially when the elite practices transform mass media into merely a mouthpiece for the political and business interests of the elites. In such condition, mass media and the circulated news tend to be very biased and misleading to the public. In fact, in some cases, a kind of "malpractice" has been detected in mass media reporting. The news reports circulated by the media were used by the elites, in this case owners of capital, to suppress their oppositions, both in politics and business, or even to promote and benefit their own business interests (Kompas.com, 2010). Other studies reveal that editorial and news content, both in printed and electronic media tend to adhere to the interests of the media's owner [2].

\footnotetext{
*Corresponding author: eriyanto09@ui.ac.id
} 
But does the influence of media owners fully affect the content of news reports? After all, news reporting include many other actors, such as journalists, as well. This question prompted the researcher to study the formation of news framing conducted in the newsroom, particularly Metro $T V$ 's formation of news framing in reporting the case of Ahok. This study aims to discover what factors influence the creation of a news content in the newsroom.

\section{Theoretical Review}

The concept of framing focuses on communication process. Communication is not static, but rather a dynamic process that involves frame-building (the creation of framing) and frame-settings (the interactions between media framing and audience's tendencies). Entman explains that the process of framing has several parts, namely communicator, text, recipient, and culture [3]. Scheufele develops a model of framing process. Similar to research on agenda building, agenda setting, and priority setting, studies of framing usually examine either the process of frame building, setting frames, or individual-level effects of framing [4].

There are several prior studies on the impacts of certain factors such as organizational boundaries, journalists' professional value, expectations of news forms, and content on audiences [5]. These studies, however, have not yet analyzed how news framing is formulated in the media or how particular types of framing is generated by the media. Therefore, further research must analyze the processes that affect the creation or alteration of news framing created by journalists. The term frame building, borrowed from research agenda settings, seems to capture this process well. The main question is, thus, what organizational or structural factors in media or what individual characteristics of journalists that can influence the creation of news framing.

Frame building refers to processes that influence journalists' formation and implementation of media framing [4]. Journalists not only report, but also shape events [6]. Journalists' active role in news framing often occurs during political news coverage [7]. In certain circumstances, the process of news framing in journalism is often in line with the interests of political actors [8]. The term frame building is taken from the research agenda setting, which is similar to Cobb and Elder's building model [9]. The main question is what organizational or structural factors of the media or the characteristics of journalists can influence the framing of news content. In addition, media strategies employed by political actors are often in line with the frames promoted by the media [10]. As part of the framing process, Scheufele separates important framing lines into inputs, processes, and outcomes [4]. The picture below conceptualizes framing as an ongoing process where the outcomes of several processes are used as input for subsequent processes. Scheufele describes four processes in which frame building is one of them. These processes are frame building, frame settings, individual-level effects of framing, and the line of relationships between individual frames and media frames [4].

Hängli argues that journalists have a very important part in the process of determining which frames will be employed by the media [11]. However, this aspect has been criticized in a study conducted by De Vreese [12]. Journalists tend to report news that contains elements of conflict [13]. What remains unclear is to what degree the agency and the intervention of journalists affect the modification of the frames so that they emphasize conflict. Concept that is relevant to this is the concept of interventionism, namely the extent to which journalists are active or passive in delivering news [14]. Journalists decide whether and how to report news about political conflict. They may seek news about political conflicts, exacerbate political conflicts to make stories more interesting, or even actively organize and produce framing conflicts. 
Among previous studies on frame building, the role of journalists and news space has not been sufficiently explored [15]. However, the practice of journalistic framing is important because framing is what journalists do; journalists cannot frame topics on their own as they need frames from their sources in producing news, leading them to inevitable alter or even supervise their own framework in the process [16].

The model of news selection process by Gans about the influence on media content shows at least three potential sources of influence [17]. The first source of influence is journalistic-centered influence. Journalists actively build frames to compile and understand incoming information. The formation of frames is moderated by variables such as ideology, attitudes, and professional norms [18]. These variables are ultimately reflected in the way journalists frame news coverage. The second factor that influences news framing is the selection of frames as a result of the type or orientation of the medium of politics, or what Gans called "organizational routines." [17]. The third source of influence is external sources, including political actors, authorities, interest groups, and other elites [5].

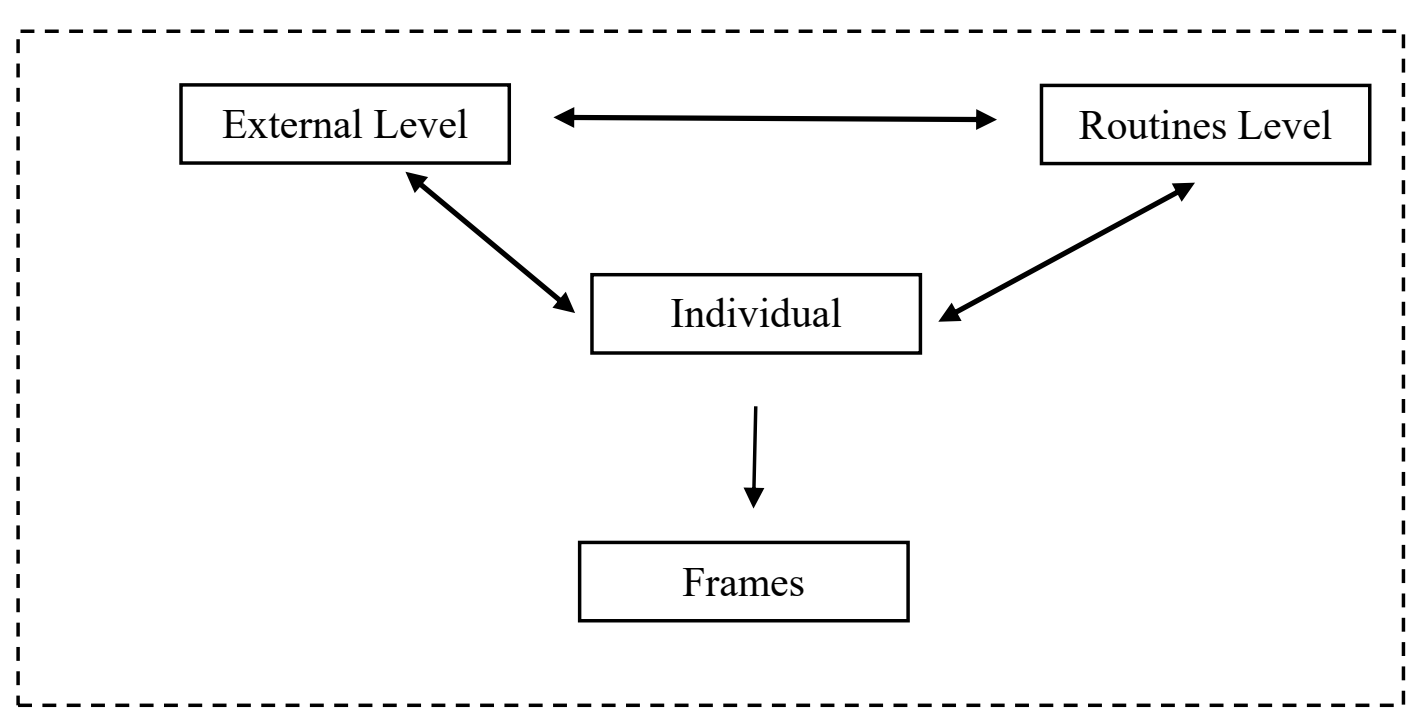

Fifure 1. Theoretical Framework

This study hypothesizes that the abovmentioned factors (individual level, external level, routines level) occurred in Metro $T V$ 's newsroom and were interrelated and interconnected, from which these factors formed a frame of news about Ahok.

In analyzing the factor of individual level, the informants of this research were asked about their opinion on Ahok; what kind of person they thought Ahok was, whether they thought Ahok was guilty of blasphemy and deserved to be named a suspect or not, and whether their opinions affected their way of producing news in Metro TV. In analyzing the factor of routines level, the questions asked to the informants were more about the structure of Metro TV's editorial; what was the position of the informants in Metro TV, from where did the ideas of Metro TV's content come from, and who was the most responsible in forming and deciding the content of Metro TV's news coverages, particulary the ones on Ahok. Finally, in analyzing the external factor, the questions asked to the informants surrounded the external matters that influenced the formation of news content, especially the role of political parties, incuding how parties possibly intervened in Metro TV's newsroom, whether there were certain things ordered by the parties, and whether there were certain sanctions if the orders were not implemented. These factors are considered to have 
their own role in Metro TV's formation of the contents and frames of its news coverages on Ahok.

\section{Research methods}

The approach employed in this research is qualitative approach, specifically the case study method. Case study is a research method that uses various data sources that can be used to study, analyze, and comprehensively describe various aspects of individuals, groups, programs, organizations or events systematically (Sagadin, 2004). This study chose Metro $T V$ as the object of research because Metro $T V$ is one of the media channels that are considered as partisan, especially in the event of the 2017 Jakarta gubernatorial election. This study used data collection techniques in gathering and analyzing interviews, observations, and documents. The researchers interviewed five Metro TV's journalists who were directly involved in the process of reporting news for a program of Metro TV. These five journalists had different roles in the reporting processes (individual level, routines level, and external level) and worked together in forming news contents.

\section{Results}

There are three aspects that comprise frame building, namely individual level, routines level, and external level.

\subsection{Individual Level}

In this case, all informants believed that Ahok actually did not commit blasphemy. They explained that the evidence presented was somewhat exaggerated. In addition, the informants also argued that the incident seemed to be based on political reasons; they assumed that the blasphemy case was intentionally publicized to prevent Ahok from being reelected as Jakarta governor. The informants explained that the uploaded and edited video was intentionally created and circulated by some actors to divert Ahok's concentration from his gubernatorial duties and reelection bid.

In conclusion, according to the respondents, Ahok was not actually guilty. This means that the informant had already embraced a prior belief about Ahok, namely Ahok's innocence from blasphemy. Similar to this belief, the informants also believed that the whole process of naming Ahok a suspect was fallacious; the majority of people only heard about Ahok's problematized statement on the Maidah verse, yet how it proceeded until he was named as suspect remained unclear. The informants believed that Ahok's prosecution was predetermined by the then existing political issues. It is inappropriate for the article to be imposed to make the trial several times. These beliefs and opinions of the informants are believed to influence the informants in making news and contents.

\subsection{Routines Level}

In making content, the informants explained that the editor in chief held the most important role in shaping news about Ahok's alleged blasphemous conduct. The informants also explained that the news contents were mostly determined by the editor, while the production and packaging of the news contents were handled by the executive producers and producers. Regardless, in the end, all news coverages required the approval of the editor in chief. 
Besides the editor in chief, there is an assumption as well that the most influential actors in shaping and circulating the news about Ahok's prosecution were the producer and reporter. The producer was responsible for designing programs and content, while reporters, who were familiar with the conditions in the field, were very instrumental in news shaping because the selection of words and diction comes from reporters, from which the manuscripts of news coverages were formed and affected the news framing. This affected the way Ahok's prosecution was reported. This is in accordance with what is stated by Entman, that journalists not only report political events, but also shape them [6]. Journalists' association in news framing is characteristic of political news coverage [7].

\subsection{External Level}

The informants explained that there was a corresponding relationship between Metro TV, Nasdem Party, and Ahok. Nasdem, whose chairman Surya Paloh is also the owner of Metro $T V$, supported Ahok. Metro TV had an editorial policy which allowed more exposure to Ahok. This certainly raised the assumption that Metro TV supported Ahok, an assumption which was supported by the majority of informants. Regardless, the informants said that the support was due to Metro TV's belief that Ahok did the right thing. Furthermore, Metro $T V$ 's support for Ahok was backed by the editor.

Some informants also explained why the assumption of Metro TV being the supporter of Ahok arose. According to the informants, this assumption emerged because Metro TV and Nasdem Party were part of Ahok's stronghold. It was also argued that this assumption emerged due to political reasons; according to the informants, certain parties later assumed that Metro TV had become biased. Whether it was indeed being politicized or not, ownership is believed to affect news content as well as journalism. Furthermore, in an attempt to maximize the TV channel's profits, it limits the diversity of news contents presented.

\section{Conclusion}

Based on the results of interviews and observations conducted by the researchers, the internal structure of Metro $T V$ resembles that of the News Factory Model, with the only difference is the structure of the workers. Regardless, Metro TV's and the News Factory Model's broadcasting procedures are the same. In this kind of structure, the producer has a considerable jurisdiction in every step of news formation, starting from the formation of ideas to the news broadcast. Similalry, reporters also have a considerable role in choosing the linguistic styles and wordings of news. However, in regard to Metro TV's structure, all informants agreed that the person who has the most significant role in formulating news framing is the editor in chief. Lastly, in formulating news, certain restrictions, such as selective determination of sources, are imposed.

\section{Acknowledgements}

This work is supported by Hibah PITTA 2018 funded by DRPM Universitas Indonesia No.2028/UN2.R3.1/HKP.05.00/2018

\section{References}


1. S. Ashley, M. Poepsel, E. Willis. JMLE 2, 37-46 (2010)

2. J.H. Snider, B.I. Page. Anuual Meeting MPSA, 1997, Evanston

3. R.M. Entman. JOC 43, 51-58 (1993)

4. D.A. Scheufele. JOC 49, 103-122 (1999)

5. P.J. Shoemaker, S.D Reese. Mediating the message:Theories of influences on mass media content (New York, Longman, 1996)

6. R.M. Entman, JOC 41, 6-27 (1991)

7. T. Cook. Governing with the news (Chicago, The University of Chicago Press, 1998)

8. M. Brüggemann. CT 24, 61-82 (2014)

9. R. Cobb, C. Elder. Participation in American Politics (Boston, Allyn and Bacon, 1972)

10. O. Ihlen, K. Thorbjørnsrud. IJSC 8, 45-60 (2014)

11. Hänggli, R. Unpublished manuscript, University of Zurich (2011)

12. C.H. De Vreese. Framing Europe: Television news and European integration (Amsterdam, Aksant, 2012)

13. D.C. Mutz, B. Reeves. APSR 99, 1-15 (2005)

14. J. Stromback, F. Esser, Frank. In K. Lundby (ed.), Mediatization : Concepts, changes, consequence (New York, Peter Lang, 2009)

15. B.T. Scheufele, D.A. Scheufele, D. A. In P. D'Angelo \& J. A. Kuypers (eds.), Doing news framing analysis. Empirical and theoretical perspectives (New York, Routledge, 2010).

16. P. D ' Angelo, J.A.Kuypers, (eds.), Doing news framing analysis. Empirical and theoretical perspectives (New York, Routledge, 2010).

17. H.J Gans, (1979). Deciding what's news (New York, Pantheon, 1979)

18. W. Donsbach. Gazette 27, 47-61 (1981) 